\title{
Doctor-Patient Interaction: A Systemic Functional Analysis
}

\author{
Isli Iriani Indiah Pane ${ }^{1}$, Amrin Saragih ${ }^{2}$, Nurlela $^{3}$, Masdiana Lubis ${ }^{4}$ \\ ${ }_{1,2,3,4}$ Postgraduate Program of Linguistics, Faculty of Cultural Sciences, \\ Universitas Sumatera Utara (USU), Medan, Indonesia \\ e-mail: isli_iriani@yahoo.com
}

Received: 25 October 2018;

Accepted: 05 November 2018

\begin{abstract}
One of the basic mediums in the interaction between doctor and patient in the treatment room is language. This paper, hence deals with the conversation in doctor-patients interaction in Pirngadi General Hospital in Medan, Indonesia. Clauses in the conversations were adopted as the main research data. The analysis is based on the theory of Systemic Functional Linguistics pioneered by Halliday (2004). The research was conducted by applying top-down approach from the analysis of the consultation in terms of context of situation that is concerned with register variables covering field, tenor and mode. Then, the analysis further focuses on the experiential function in terms of transitivity system covering the analysis of the processes used the participant functions involved and the interpersonal function covering mood and modality. The study was conducted by using descriptive qualitative method with triangulation. It refers to the use of multiple methods or data sources in qualitative research to develop a comprehensive understanding of phenomena. Triangulation is viewed as a qualitative research strategy to test validity through the convergence of information from different sources. The results of the analysis have revealed that social relation exists in the language used by the doctor and the patient in their interaction in which the doctor has more power over the patient.
\end{abstract}

Keywords: systemic functional linguistics, interaction, register variables.

\section{Introduction}

Researches about doctor-patient interaction have been conducted by some researchers or linguists using different theories and methodologies (see Valero-Garces 2002, Chimombo and Roseberry 1998, Wodak 1997, Myerscough 1992, Van Naerssen 1985, Coleman and Burton 1985, Labov and Fanshel 1977, and Coulthard and Ashby 1976). As doctor-patient interaction takes place in different institutional settings, such as hospitals or private clinics, a large proportion of time is spent in talking and listening. Being one basic medium of doctorpatient interaction, talking should play a crucial part in the process of patients' healthiness development.

There are differences between spoken and written discourses. Written language is often considered more complex than spoken language. Halliday (2001) argued that this is a misinterpretation. Spoken and written languages tend to display different kinds of complexity and each of them is complex in its own way. The difference between the two 
modes as "written language tends to be lexically dense, but grammatically simple; spoken language tends to be grammatically intricate, but lexically sparse." Written language is likely to consist of a larger number of lexical items in each clause, which makes the clauses lexically dense; whereas spoken language is likely to line up more clauses and add subordinate clauses to elaborate the details, which makes the clauses grammatically intricate (Halliday, 2002).

\section{Literature Review}

A useful methodological framework for studying language in context, whether it be the context of science, advertising, children's nursery rhymes, or indeed any other context of situation, is offered by Systemic Functional Linguistics (SFL). SFL describes "language in use" rather than language as a "set of generalized rules detached from any particular context of use" (Thompson, 2004: 1). Language and context are inextricably linked according to SFL theory, and such a model is therefore useful in identifying and describing text types. The SFL approach divides language into three semantic functions, or metafunctions, which together represent meaning as it is construed in language. The three metafunctions are (1) ideational metafunction, (2) interpersonal metafunction, and (3) textual metafunction.

In each metafunction, an analysis of a clause gives a different kind of structure composed from a different set of elements.

(1) The ideational metafunction is about the natural world in the broadest sense, including our own consciousness, and is concerned with clauses as representations. In this type of metafunction, a clause is analysed into (1) Process, (2) Participants, and (3) Circumstances, with different participant types for different process types. Experiential meaning is concerned with the "things" that we can talk about, and logical meaning with the interdependency relationships that language allows us to construct between these things. It is important to note that logical meaning is concerned with the logic of a language and not with formal or mathematical logic which is based on and develops from logical expressions of language. Ideational meaning is realized in what Halliday refers to as the transitivity system and systems concerned with the interdependency relations between units in a clause complex.

(2) The interpersonal metafunction is about the social world, especially the relationship between speaker and hearer, and is concerned with clauses as exchanges. Interpersonal meaning is mostly realized in the mood and modality systems of a language. Ideational meaning is concerned with what has traditionally been referred to as semantics. It is concerned with the way in which language mediates about the reality which we assume to be in us and around us, both real and imagined; it is concerned with the way in which language serves as a model of reality. It can be subdivided into experiential and logical meaning.

(3) The textual metafunction is about the verbal world, especially the flow of information in a text, and is concerned with clauses as messages. Textual meaning relates to the way in which language makes links with itself and with the situations in which it is used. Speech (and writing) is not just a random collection of words that are unrelated 1) to what the speaker (or someone else) has just said (or written) or 2) to the context in which they are uttered. Textual meaning is made manifest in the resources that allow the speaker to create a coherent text, one that makes sense in the context in which it is being uttered and in the context of what has been uttered and will be uttered. It is mostly realized in the theme and information focus system. These types of meaning are referred to as "metafunctions" 
because they are a result of a number of very broad and abstract uses that language has evolved to serve.

The metafunctions can be seen as the "interface" which links language to other semiotic systems, they provide a link between language and what is outside language (Thibault 1987: 608). They link up with another interface, the context of situation, which is defined by Halliday (Thibault 1987: 610) as a "generalized semiotic construct": The context of situation is a generalized semiotic construct deriving from the culture) something that is recognized by the members as a form of social activity that they engage in. Contexts of situation are characterized by Halliday (e.g. 1978: 61-62, 142- 145, 221-230; Halliday \& Hasan 1985: $12-$ 14, 56-69) in terms of three dimensions: 1) field, 2) tenor, and 3) mode, each of which can be simply glossed as 1) what is happening, 2) who is taking part, and 3) the role of language in the linguistic contact.

\subsection{Transitivity System}

Thompson (2014: 94) mentions the term transitivity will probably be familiar as a way of distinguishing between verbs according to whether they have an object or not. However, it is used in a much broader sense. In particular, it refers to a system for describing the whole clause, rather than just the verb and its object. It does, though, share with the traditional use a focus on the verbal group, since it is the type of process that determines how the participants are labelled: the 'doer' of a physical process such as kicking is given a different label from the 'doer' of a mental process such as wishing. At this informal level 'doer' seems less appropriate as a label in the case of the mental process.

The functional configurational realization of the transitivity system, in its most canonical format, is presented in Figure 2.1:

\begin{tabular}{|l|l|l|l|l|}
\hline $\begin{array}{l}\text { TRANSITIVITY } \\
\text { CONSTITUENTS }\end{array}$ & Participant & Process & (Participant) & (Circumstance) \\
\hline $\begin{array}{l}\text { CLASSES THAT } \\
\text { INSTANTIATE } \\
\text { CONSTITUENTS }\end{array}$ & $\begin{array}{l}\text { Nominal } \\
\text { Group }\end{array}$ & $\begin{array}{l}\text { Verbal } \\
\text { Group }\end{array}$ & $\begin{array}{l}\text { Nominal } \\
\text { Group }\end{array}$ & $\begin{array}{l}\text { Adverbial } \\
\text { Group or } \\
\text { Prepositional } \\
\text { Phrase }\end{array}$ \\
\hline
\end{tabular}

Figure 2.1 Configurational realization of transitivity

\subsubsection{Process}

At the layer of the transitivity system, the clause is analyzed for its potential to represent both the outer and the inner worlds of human beings, which is what the ideational metafunction does. The representation of reality is achieved by means of a set of processes, along with their participants and the circumstances in which they unfold.

In the transitivity system, there are six types of process, i.e. (1) material, (2) mental (cognition, perception, affection), (3) relational, (4) behavioral , (5) verbal, and (6) existential. The participants related to each are: Material $\rightarrow$ Actor (obligatory) and Goal (optional); Mental $\rightarrow$ Senser and Phenomenon (both are always potentially present; either may, however, be implicit); Relational $\rightarrow$ Attributive type: Carrier and Attribute OR Identifying type: Identifier and Identified; Behavioral $\rightarrow$ Behaver; Verbal $\rightarrow$ Sayer, Verbiage, Receiver, Target; Existential $\rightarrow$ Existent. 
Doctor-Patient Interaction: A Systemic Functional Analysis, Isli Iriani Indiah Pane, Amrin Saragih, Nurlela, Masdiana Lubis

\begin{tabular}{|l|l|l|}
\hline \multicolumn{1}{|c|}{ Process type } & \multicolumn{1}{|c|}{ Category Meaning } & \multicolumn{1}{|c|}{ Participants } \\
\hline $\begin{array}{l}\text { material: } \\
\text { action } \\
\text { event } \\
\text { 'doing' } \\
\text { 'doing' }\end{array}$ & Actor, Goal \\
\hline Behavioral & 'behaving' & Behaver \\
\hline $\begin{array}{l}\text { mental: } \\
\text { perception } \\
\text { affection } \\
\text { cognition }\end{array}$ & $\begin{array}{l}\text { 'sensing' } \\
\text { 'seeing' } \\
\text { 'feeling' } \\
\text { 'thinking' }\end{array}$ & $\begin{array}{l}\text { Senser, } \\
\text { Phenomenon }\end{array}$ \\
\hline $\begin{array}{l}\text { Verbal } \\
\text { 'saying' }\end{array}$ & Sayer, Target \\
\hline $\begin{array}{l}\text { relational: } \\
\text { attribution } \\
\text { identification }\end{array}$ & $\begin{array}{l}\text { 'being' } \\
\text { 'attributing' } \\
\text { 'identifying' }\end{array}$ & $\begin{array}{l}\text { Token, Value } \\
\text { Carrier, Attribute } \\
\text { Identified, Identifier }\end{array}$ \\
\hline Existential & 'existing' & Existent \\
\hline
\end{tabular}

Figure 2.1.1 The Process type Category Meaning Participants (Halliday, 1985: 131)

\subsubsection{Participant}

There are two participants in mental processes, namely Senser and Phenomenon. Halliday and Matthiessen (2004: 201) state that Senser is "the conscious being that is feeling, thinking, wanting, or perceiving" and that Phenomenon is "that which is 'sensed'- felt, thought, wanted or perceived" (2004: 203). Halliday and Matthiessen (2004: 205) state that Phenomenon in emotion verbs in mental processes is typically a thing, fact and situation. Mental processes usually constitute by Senser that is followed by Process and Phenomenon. This pattern of participants order constituent can be accepted as an active form of mental processes. On the other hand, Halliday and Matthiessen (2004: 200) state if there is an active form in mental process, there is also a passive form of mental process, with phenomenon as the fronted element, followed by Process and of course, Senser, as in data.

\begin{tabular}{|l|l|l|}
\hline Frank & loves & science \\
\hline Senser & Process: Mental & Phenomenon \\
\hline
\end{tabular}

\subsubsection{Circumstance}

Circumstances are elements that can be found in all six processes in functional grammar, especially in mental processe. Circumstances are optional participants in mental processes. It means that it is nothing necessarily needed former a mentally process to have a Circumstance element. Halliday and Matthiessen (2004: 260) mention Circumstances refer to examples such as the location of an event in time or space, its manner, or its cause, and these notions of when, where, how, and why the things happens provided by... explanation, by linking circumstance to the four WH-forms that were adverbs. In additional, Eggins (2000: 237-239) states that there are seven elements of circumstantial that can be found in processes, i.e.(1) Extent; (2). Location; (3). Manner; (4). Cause; (5). Accompaniment; (6). Matter; and (7). Role. Circumstantial element of extent answers the question about duration (How long? and How many times?) and spatial distance (How far?) is called Extent circumstance. Circumstantial element of location answers the question about temporal (When?) and spatial (Where?). Circumstantial element of manner answer the question about means (How? and Whit what?), quality (How? and How -ly?), and comparison (What... 
like?). Circumstantial element of cause answers the question about cause (Why?), reason (What for?), and behalf (Who for?).

Circumstantial element of accompaniment answers the question of with whom; circumstantial element of matter answers the question of what about and circumstantial element of role answers the question of what as.

\section{Research Method}

There are four aspects that should be mentioned in this part, i.e. (1) The triangulation, (2) Types of Triangulation Used, (3) Data collection procedures, and (4) Data analysis.

\subsection{Triangulation}

In this analysis, the concept adopted is triangulation. Patton (1999) mentions triangulation refers to the use of multiple methods or data sources in qualitative research to develop a comprehensive understanding of phenomena. Triangulation also has been viewed as a qualitative research strategy to test validity through the convergence of information from different sources. Denzin (1978) and Patton (1999) identified four types of triangulation: (a) method triangulation, (b) investigator triangulation, (c) theory triangulation, and (d) data source triangulation. Since "different methods have different strengths and weaknesses" (Gillham, 2000) the "effectiveness of triangulation rests on the premise that the weakness in each single method will be compensated by the counterbalancing strengths of another" (Jick, 1979). With triangulation, researchers can use two research methods to decrease the weaknesses of an individual method and strengthen the outcome of the study (Denzin 1978, Sharif and Armitage 2004).

Hence, triangulation can potentially elevate researchers above personal biases that emanate from a single methodology.

\subsection{Types of Triangulation Used in this Study}

Three types of triangulation that have been employed in this paper, i.e. (a) data triangulation, (b) theory triangulation, and (c) methodological triangulation. Data triangulation involves collecting and using data from male, female, patients as well as male doctors in public/general hospital in Medan city. For theory triangulation, SFL has been employed as theoretical tools. Methodological Triangulation is defined by Kimchi et al. (1991) as the use of two or more research methods in a single study. The difference can be at the level of design or data collection. LoBindoWood and Haber (1998) identified two different types of methodological triangulation: the within method triangulation which is used when the phenomenon being studied is multidimensional; and the across method or between method triangulation which involves combining research strategies from two or more research traditions in the same study.

The data were collected from Pirngadi General Hospital in Medan in the forms of recordings. Then these records were transcribed. There were two Transcripts of doctorpatient interactions, i.e. Transcript 01 consists of 27 clauses (doctor $=15$ clauses and patient=12 clauses); and Transcript 02 consists of 94 clauses (doctor $=81$ clauses and patient $=13$ clauses). So, the total clauses analyzed in this paper were: 96 clauses uttered by the doctor and 25 clauses uttered by the patients. All of the clauses were categorized as clause simplexes. 
Doctor-Patient Interaction: A Systemic Functional Analysis, Isli Iriani Indiah Pane, Amrin Saragih, Nurlela, Masdiana Lubis

The reasons of selecting these data were two folds. First of all, a live record of a doctorpatient interaction at a consultation in a particular place and time can provide both pictures and sound which serve much better than a written text in seeing how interactants create the discourse and what language patterns occur in the context. Then, the second reason was the data resource convenient to access on quality from various viewers.

\section{Results and Discussion}

In order to get the results of the analysis on the Transitivity systems of the data (doctorpatient interactions), all of transitivity elements exist were analyzed, i.e. (1) Process, (2) Circumstance, and (3) Participants. The target of the analysis was to get the dominant uses of the transitivity elements in both doctor and patient clauses.

The following Tables show all the processes used in doctor-patient interaction:

Tabel 1: Process Types of clauses uttered by the doctor

\begin{tabular}{|l|c|c|}
\hline \multicolumn{1}{|c|}{ PROCESS } & DOCTOR & $\%$ \\
\hline Material & 26 & 27.08 \\
\hline Relational Identifying & 19 & 19.7 \\
\hline Relational Attributive & 4 & 4.1 \\
\hline Mental & 34 & 35.4 \\
\hline Verbal & 4 & 4.1 \\
\hline Behavioural & - & - \\
\hline Existential & 9 & 9.3 \\
\hline & 96 & 100 \\
\hline
\end{tabular}

Tabel 2: Process Types clauses uttered by the patient

\begin{tabular}{|l|c|c|}
\hline \multicolumn{1}{|c|}{ PROCESS } & PATIENT & $\%$ \\
\hline Material & 7 & 28.8 \\
\hline Relational Identifying & 4 & 16.0 \\
\hline Relational Attributive & 2 & 8.0 \\
\hline Mental & 10 & 40.0 \\
\hline Verbal & 2 & 8.0 \\
\hline Behavioural & - & - \\
\hline Existential & - & - \\
\hline & 25 & 100 \\
\hline
\end{tabular}

The following is the comparisons of Process types in both doctor and patient clauses in the form of graphs:

Process Types: Doctor's clauses

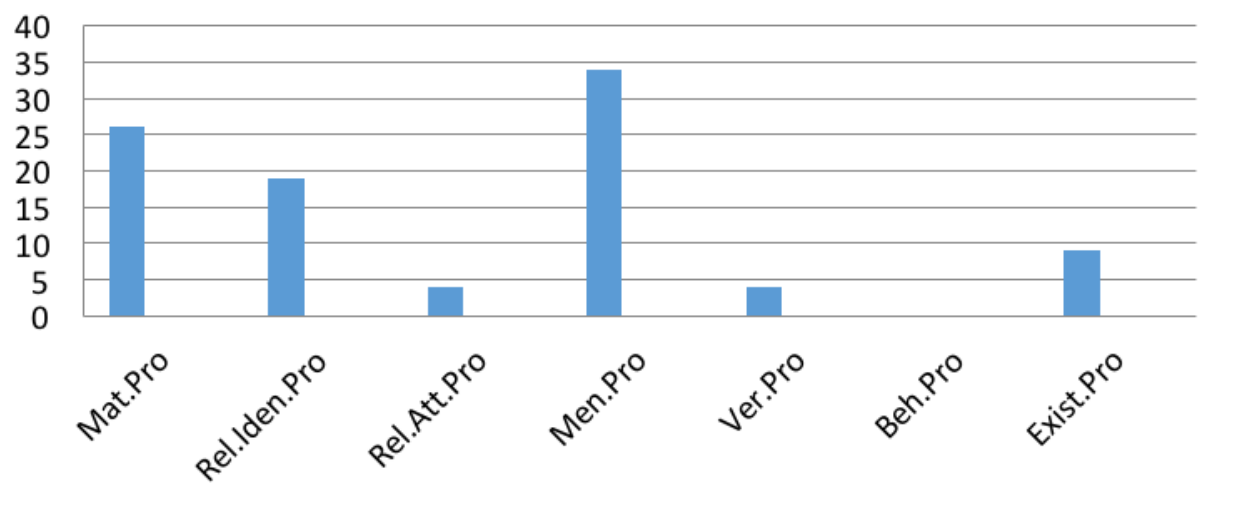




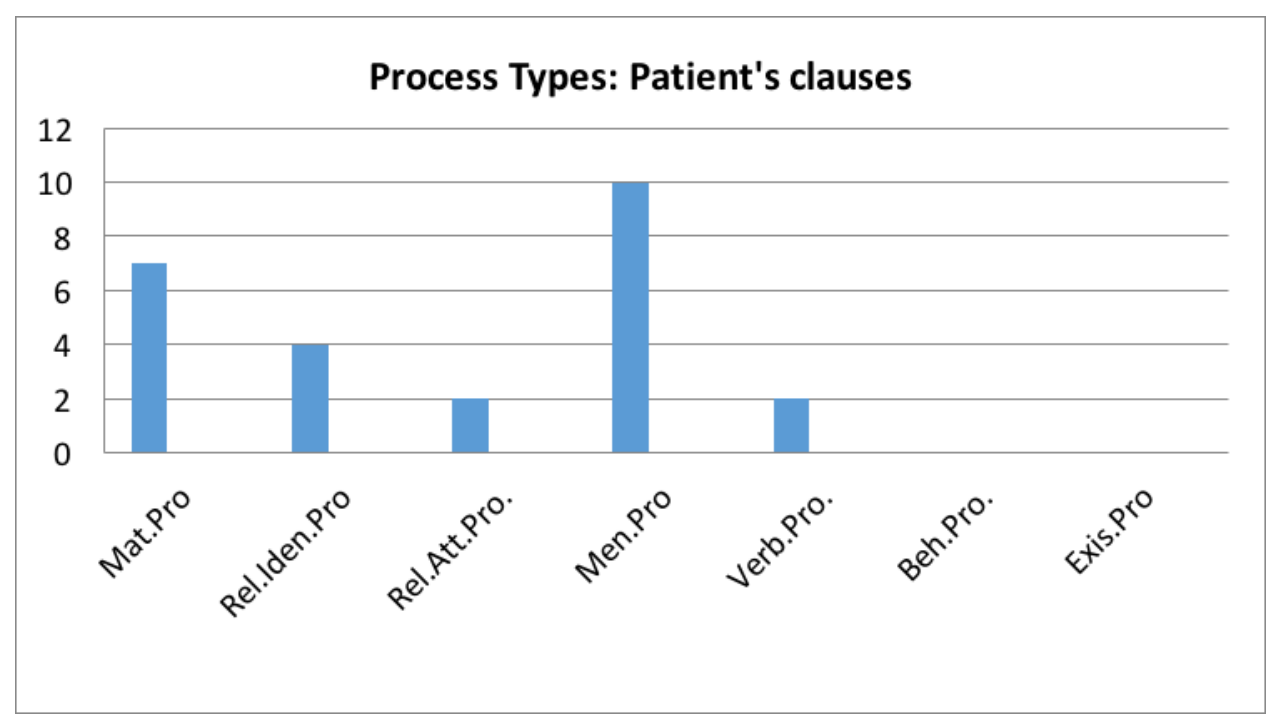

Table 1 deals with the number of each process found in doctor's clauses. It figures out the comparison amongst the processes found in clauses uttered by the doctor. The total number of processes found in these utterances spread out in 96 clauses. In this case, Mental Process was dominantly used by the doctor, i.e. $35.4 \%$. The other three processes frequently used were Material Process $=27.08 \%$, and Relational Identifying Process) $=19.7 \%$.

In comparison, Table 2 deals with the number of each process found in patient's clauses as the respond in the interaction. It figures out the comparison amongst the processes found in clauses uttered by the patient. The total number of the processes found in these utterances spread out in 25 clauses. In this case, Mental Process was dominantly used by the patient, i.e. $4.0 \%$. The other three processes frequently used were Material Process $=28.8 \%$, and Relational Identifying Process) $=16.0 \%$.

By identifying the number of the overall processes, it can be summarized that the doctor and the patient have the same domination in the use of the major transitivity systems, i.e. $82.1 \%$ processes. Mental Process $=35.4 \%$. Material Process $=27.08 \%$, and Relational Identifying Process) $=19.7 \%$ in doctor's clauses from $84.8 \%$ processes there were $40.0 \%$ for Mental Process $28.8 \%$ for Material Process, and $16.0 \%$ for Relational Attributive Process.

Overall across the four sources of data, 121 processes were uttered by both doctor ( 96 processes) and patient 25 processes. The doctor used 96 processes representing $79.3 \%$ of the total whilst the patient uttered 25 processes representing $20.6 \%$ of the total. In summary, the percentage difference reveals that in terms of transitivity system, the doctor apparently has the upper hand enabling him to control the course of the interaction.

In the matter of difference, the material processes uttered by the doctor $(27.08 \%)$ different slightly from that used by the patient (28.8\%). There is also a slightly percentage difference between the Relational Attributive Process uttered by the doctor (4.1\%) and the patient (8.0\%). However, there is major difference between the Existential Process used by the doctor $(9.3 \%)$ and those of the patient $(0 \%)$. This shows that the doctors in their communication with their patients do a lot of factual things in the course of conversation in the treatment room. The doctor also seems to have responded well to the patients' emotional needs in the encounter. Both interactants used most of the process types (material, mental, relational, verbal, and except Behavioural Process). Therefore, it can be 
Doctor-Patient Interaction: A Systemic Functional Analysis, Isli Iriani Indiah Pane, Amrin Saragih, Nurlela, Masdiana Lubis

concluded that the patient is given a voice to express her views and concerns in the encounter.

The samples of data of each process can be seen in the following:

1. Bisa tambah obat batuk buk?

'Can you add the expectorant, Mam?'

\begin{tabular}{|l|l|l|}
\hline Bisa tambah & obat batuk & \multicolumn{1}{|c|}{ buk! } \\
\hline Material Pr. & Goal & Actor \\
\hline
\end{tabular}

2. Parah kali batuknya, dok

'The cough is very severe, doc'

\begin{tabular}{|l|l|}
\hline Parah kali batuknya & dok \\
\hline Mental Pr. & \\
\hline
\end{tabular}

3. Obat yang sekali sebulan bisa dok? Untuk yang menggantikan apanya itu nanti, sekali datang.

'Can I have the medicine which is taken once a month, Doc? To replace it later, in one visit'

\begin{tabular}{|l|l|l|}
\hline $\begin{array}{l}\text { Obat yang sekali } \\
\text { sebulan bisa dok? }\end{array}$ & (yaitu) & $\begin{array}{l}\text { untuk yang menggantikan apanya itu } \\
\text { nanti, sekali datang. }\end{array}$ \\
\hline Carrier & Relational Pr. & Attribute \\
\hline
\end{tabular}

4. Aku nanyak buk.

'I ask, Mam.'

\begin{tabular}{|l|l|l|}
\hline Aku & nanyak & buk \\
\hline Sayer & Verbal Pr. & Receiver \\
\hline
\end{tabular}

5. Sekarang ibu ngeluhannya apa?

'Now, how do you feel Mam?'

\begin{tabular}{|l|l|l|l|}
\hline Sekarang & Ibu & ngeluhannya & apa? \\
\hline Circ.Lok Time & Senser & Mental Pr. & Phenomenon \\
\hline
\end{tabular}

6. Tungkai mana buk? kanan apa kiri?

'Which leg, Mam? Right or left?'

\begin{tabular}{|l|l|l|l|}
\hline Tungkai & mana & buk? & kanan apa kiri? \\
\hline Existence & Exisistential Pr. & & Circ.Loc.Place \\
\hline
\end{tabular}

7. ini ada lagi

'There is one more'

\begin{tabular}{|l|l|l|}
\hline ini & Iagi \\
\hline Carrier & Rel.Pro.Attr. & Cir.Extent \\
\cline { 2 - 3 }
\end{tabular}

8. Nanya dulu? Ini maksudnya apa ini?(kesana dulu..kesana dulu..)

'Asking first? What does it mean?' (go there first..go there first..)

\begin{tabular}{|l|l|l|l|l|l|}
\hline Nanya & dulu? & Ini & apa ini & maksudnya? & $\begin{array}{l}\text { (kesana } \\
\text { dulu..kesana dulu..) }\end{array}$ \\
\hline
\end{tabular}




\begin{tabular}{|l|l|l|l|l|}
\hline $\begin{array}{l}\text { Verbal Acc.Cont } \\
\text { Pr. }\end{array}$ & Verbiage & Verbiage & Verb.Pro & Verbiage \\
\hline
\end{tabular}

9. Normalnya 11.000 ya dok

'The normal amount is 11.000, isn't it, Doc?'

\begin{tabular}{|l|l|l|}
\hline Normalnya & (adalah) & 11.000 ya dok \\
\hline Carrier & Rel.Attr. Pro & Attributive \\
\hline
\end{tabular}

\section{Conclusion}

The analysis in this paper brings out a number of differences between two short texts, i.e. utterances uttered by doctor and patient in their interactions. The results of the analysis show that there is a major difference in using some processes, i.e. between the Existential Process used by doctors (9.3\%) and those by patient (0\%). This shows that the doctor does a lot of factual things in the course of the encounter. The doctor also seems to have responded well to the patients' emotional needs in the encounter. Both interactants used most of the process types (material, mental, relational, verbal, and except Behavioural Process). Therefore, it can be concluded that the patient is given a voice to express her views and concerns in the encounter.

\section{Acknowledgements}

This research was supported by Universitas Sumatera Utara. I thank my colleagues from Universitas Sumatera Utara who provided insight and expertise that greatly assisted the research, although they may not agree with all of the interpretations and conclusions of this paper.

I personally thank Prof. Amrin Saragih, M.A., Ph.D., Dr. Nurlela, M.Hum., Dr. Masdiana Lubis for their assistance with particular technique, methodology, and inputs that greatly improved the manuscript.

I would also like to show my gratitude to the head and secretary of Linguistic Study Programme of Universitas Sumatera Utara, Dr. Eddy Setia and Dr. Edi Mulyadi, M.Hum., for sharing their pearls of wisdom with me during the course of this research, and I thank 3 "anonymous" reviewers for their so-called insights. I am also immensely grateful to Prof. T. Silvana Sinar, Ph.D., for her comments on an earlier version of the manuscript, although any errors are my own and should not tarnish the reputations of these esteemed persons.

\section{References}

Denzin, N. K. (1978). Sociological methods: A sourcebook. New York, NY: McGraw-Hill.

Eggins, S. (1994). An Introduction to Systemic Functional Linguistics. London: SE, Martin's Press

Eggins, S., \& Martin, J. R. (1997). Genres and registers of discourses. In T. van Dijk (Ed.), Discourse studies: a multidisciplinary introduction (pp. 230-257). London: Sage Publications.

Eggins, S \& Slade, D. (2001). Analysing Casual Conversation. London: Continuum.

Eggins, S. (2004) An Introduction to Systemic Functional Linguistics. London: Pinter.

Gillham, B. (2000) The Research Interview. London: Continuum.

Halliday, M. (1979). Language as social semiotic. London: Arnold. 
Doctor-Patient Interaction: A Systemic Functional Analysis, Isli Iriani Indiah Pane, Amrin Saragih, Nurlela, Masdiana Lubis

Halliday, M. A. K. (1985). Systemic Background. In Benson, J.D. and W.S Greaves (eds) Systemic Perspective on Discourse, Vol. I, Norwood: Ablex Publishing

Halliday, M., \& Hasan, R. (1989) Language, context, and text: Aspects of language in a socialsemiotician perspective (2nd ed.). Oxford: Oxford University Press.

Halliday. M.A.K. \& Martin J.R. (1993). Writing Science: literacy and discursive power. London: Falmer Press

Halliday. M.A.K. (1994). An Introduction to Functional Grammar. London: Edward Arnold

Halliday, M. (1996). Literacy and linguistics: A functional perspective. In R. Hasan \& G. Williams (Eds.), Literacy in Society (pp.339-376). London: Longman.

Halliday, M., \& Matthiesen, C. (2004). An introduction to functional grammar. London: Arnold.

Jick, T. D. (1979), Mixing qualitative and quantitative methods: triangulation in action, Administrative Science Quarterly, Vol 24 No.4, pp.602-611.

Kimchi, T., Xu, J., and Dulac, C. (2007). Nature, in press. Published online August 5, 2007. 10.1038 /nature06089.

LoBiondo-Wood, G., \& Haber, J. (1998). Nursing research: Methods and critical appraisal for evidence-based practice. Elsevier Health Sciences.

Patton, M.Q. (1999). Enhancing the quality and credibility of qualitative analysis. Health Sciences Research, 34, 1189-1208.

Sharif, F., \& Armitage, P. (2004). The effect of psychological and educational counselling in reducing anxiety in nursing students. Journal of Psychiatric \& Mental Health Nursing, 11(4), 386-392.

Thibault, Paul J. (1987). "An Interview with Michael Halliday". In Ross Steele \& Terry Threadgold (Eds.), Language Topics: Essays in Honour of Michael Halliday, Volume II. John Benjamins: Amsterdam. Pp. 601-627.

Thompson, G. (2004). Introducing Functional Grammar (2nd ed.). London: Hodder Arnold. 